\title{
KETERBACAAN WACANA DALAM BUKU TEKS BAHASA INDONESIA "EKSPRESI DIRI DAN AKADEMIK" CETAKAN KEDUA MELALUI CLOZE TEST SISWA KELAS X SMAN 1 MAKASSAR
}

\author{
Khairil, Salam, dan Andi Fatimah Junus \\ Fakultas Bahasa dan Sastra, Universitas Negeri Makassar \\ Jalan Daeng Tata Raya, Kampus Parangtambung, Makassar \\ Email: khairilhamka@gmail.com
}

\begin{abstract}
The Readability of the Indonesian Textbook Discourse "Ekspresi Diri dan Akademik" Second Edition Using Cloze Test Methode On Grade X SMAN 1 Makassar. This research aimed to describe the readability of discourse in the Indonesian textbook "Ekspresi Diri dan Akademik" Second Edition on grade X SMAN 1 Makassar. The method used in this research is a quantitative survey methods that describe the readability level of the Indonesia textbook "Ekspresi Diri dan Akademik" Second Edition on grade X at SMAN 1 Makassar. The population of this research was all students of grade X at SMAN 1 Makassar. Sampling on this population was selected by using cluster random sampling. The sample in this research there were two classes, X MIA 5 and X IIS 3. Data collection techniques in this research is the cloze test. Data obtained using the formula cloze test. The results showed that out of the eight tested discourse to the students there are six discourse that is at the readability level independent/easy. There is a discourse belonging to the category of reading level instructional/medium. Average readability level was $68 \%$ overall discourse in the category reading level independent/easy, indicating that the level of discourse is very high readability. Results like that makes the discourse in the Indonesian Textbooks "Ekspresi Diri dan Akademik" Second Edition on grade X published by the Ministry of Education and Culture is not good enough to be used as teaching materials.
\end{abstract}

\begin{abstract}
Abstrak. Keterbacaan Wacana dalam Buku Teks Bahasa Indonesia "Ekspresi Diri dan Akademik" Cetakan Kedua Melalui Cloze Test Siswa Kelas X SMAN 1 Makassar. Penelitian ini bertujuan untuk mendeskripsikan keterbacaan wacana dalam buku teks Bahasa Indonesia "Ekspresi Diri dan Akademik" Cetakan Kedua kelas X SMAN 1 Makassar. Metode penelitian yang digunakan dalam penelitian ini adalah metode survei kuantitatif yang mendeskripsikan keterbacaan buku teks bahasa Indonesia "Ekspresi Diri dan Akademik" cetakan kedua pada siswa kelas X SMAN 1 Makassar. Populasi penelitian ini adalah seluruh siswa kelas X SMAN 1 Makassar. Penarikan sampel dilakukan dengan teknik Cluster Random Sampling. Sampel dalam penelitian ini ada 2 kelas, yaitu kelas X MIA 5 dan kelas X IIS 3. Teknik pengumpulan data pada penelitian ini adalah cloze test. Data yang diperoleh dengan menggunakan rumus cloze test. Hasil penelitian menunjukkan bahwa dari delapan wacana yang diujikan kepada siswa ada enam wacana yang berada pada tingkat baca independen/mudah. Terdapat satu wacana yang tergolong kategori tingkat baca instruksional/sedang. Rata-rata tingkat baca keseluruhan wacana adalah $68 \%$ berada pada kategori tingkat baca independen/mudah yang menandakan bahwa tingkat keterbacaan wacana sangat tinggi. Hasil seperti itu menjadikan wacana yang ada dalam Buku Teks Pelajaran Bahasa Indonesia "Ekspresi Diri dan Akademik" Cetakan Kedua pada Siswa Kelas X yang ditulis oleh Kementerian Pendidikan dan Kebudayaan masih kurang baik untuk dijadikan sebagai bahan ajar.
\end{abstract}

Kata Kunci: Keterbacaan, buku teks, cloze tezt

Buku teks merupakan suatu benda yang mutlak dimiliki oleh setiap sekolah pada tingkat sekolah menengah atas dalam rangka menunjang kegiatan pembelajaran yang akan dilaksanakan oleh setiap siswa. Dengan adanya buku teks siswa dapat terbantu dalam belajar dan tentunya dalam pengembangan dirinya. Seperti yang diungkapkan (Patombongi dkk., 2008; 7) buku teks adalah sarana belajar yang biasa digunakan di sekolah-sekolah untuk menunjang suatu 
program pengajaran. Jadi, buku teks bisa dianggap sebagai komponen atau bagian yang penting dalam proses pembelajaran.

Sebagai sarana belajar, buku teks semestinya mudah dipahami bagi pengajar maupun pebelajar. Untuk itu, buku teks perlu menampilkan informasi yang jelas dan teliti, yaitu dengan menampilkan kalimat yang tidak rancu dan tidak bermakna ambigu. Penyusunan kalimat dipilih dengan tepat, sesuai dengan kaidah bahasa yang berlaku, sehingga tidak membingungkan siswa untuk memperoleh informasi yang ingin diketahuinya. Bahasa yang digunakan dalam buku teks tentunya menjadi salah satu faktor penting yang ikut serta dalam menentukan misi buku teks sebagai bahan penunjang utama pada program pembelajaran. Pemakaian bahasa dalam buku teks akan menentukan apakah buku teks tersebut mudah dipahami atau sukar dipahami oleh siswa.

Penggunaan kalimat yang rancu serta ambigu dapat menghambat siswa dalam belajar memahami wacana yang ada di dalam buku teks. Agar buku teks memenuhi syarat dan tujuan yang diinginkan, maka tingkat keterbacaan harus sesuai dengan tingkat perkembangan kemampuan dan penalaran siswa. Pentingnya kesesuaian tingkat keterbacaan suatu buku akan sangat berpengaruh pada motivasi dan minat baca untuk siswa. Sehingga, patut diduga bahwa tingkat keterbacaan akan menentukan mudah atau tidaknya bahan bacaan dapat dipahami oleh siswa. Maksudnya, buku teks yang mudah dipahami adalah buku teks yang memiliki tingkat keterbacaan tinggi sedangkan buku teks yang sukar dipahami adalah buku teks yang memiliki tingkat keterbacaan yang rendah. Secara garis besar buku teks yang mudah dipahami akan mempercepat siswa memahami maksud dari wacana di dalam buku teks.

Sebaliknya, buku teks yang sukar dipahami akan memperlambat siswa dalam memahami maksud dari wacana dalam buku teks. Akan tetapi perlu digaris bawahi disini bahwa jika suatu wacana itu terlalu mudah, seorang pembaca dalam hal ini siswa, akan cepat merasa bosan. Maka dari itu, perlu adanya pertimbangan-pertimbangan yang tepat untuk menetapkan wacana yang dianggap sesuai untuk kelompoknya.

Pada penelitian ini, fokus peneliti adalah mengenai keterbacaan wacana buku teks bahasa indonesia untuk siswa kelas $\mathrm{X}$ sekolah menengah atas. Topik ini dipilih karena pembelajaran bahasa indonesia di sekolah menengah atas sangat penting. Hal ini karena bahasa indonesia akan menjadi bekal bagi siswa dalam berkomunikasi dengan lingkungannya kelak pada jenjang yang lebih tinggi. Bahasa merupakan sarana komunikasi bagi siswa untuk berbaur, sehingga mampu menyatu dengan masyarakat pemakai bahasa lainnya, di tengahtengah beranekaragam bahasa nusantara.

Dengan demikian, untuk mengetahui sesuai atau tidak buku teks yang digunakan siswa kelas $\mathrm{X}$ dengan karakteristiknya, maka penelitian mengenai keterbacaan buku teks Bahasa Indonesia di kelas X sekolah menengah atas perlu dilakukan. Dalam hal ini, buku teks Bahasa Indonesia "Ekspresi Diri dan Akademik" cetakan kedua untuk siswa kelas $\mathrm{X}$ yang akan diteliti ini memang telah disesuaikan dengan kurikulum yang berlaku sekarang, yakni kurikulum 2013. Namun, setelah melakukan observasi awal, peneliti menemukan bahwa minat baca siswa terhadap wacana-wacana di dalam buku tersebut masih kurang.

Atas dasar tersebut, maka sangat perlu penelitian keterbacaan buku teks Bahasa Indonesia "Ekspresi Diri dan Akademik" untuk siswa kelas X cetakan kedua ini, dengan harapan penelitian ini dapat digunakan sebagai bahan pertimbangan oleh guru yang menggunakan buku teks tersebut.

Untuk memilih formula yang tepat dan sesuai untuk mengukur keterbacaan maka peneliti harus cermat memilih formula yang akan digunakan. Di antara formula yang ada, yang dianggap paling berhasil adalah prosedur klose. Prosedur ini di samping dapat digunakan sebagai alat uji keterbacaan, juga dapat digunakan sebagai teknik pengajaran membaca untuk meningkatkan keterampilan membaca siswa. (Suladi dkk, 2000; 9) Oleh sebab itu, peneliti akan menggunakan formula Prosedur Klose/Cloze Test atau biasa juga disebut dengan tes isi rumpang untuk mengetahui tingkat keterbacaan siswa kelas X di SMAN 1 Makassar terhadap wacana pada buku teks Bahasa Indonesia "Ekspresi Diri dan Akademik" untuk siswa kelas $\mathrm{X}$.

Penelitian mengenai keterbacaan buku teks sudah pernah dilakukan sebelumnya, salah satu penelitian (Magdalena, 2013) Universitas Negeri Jakarta (UNJ) meneliti tentang Keterbacaan Buku Teks "Bina Bahasa 
Indonesia" untuk Siswa Kelas V Terbitan E di SDN Pademangan Timur 04 Petang Jakarta Utara Melalui Metode Fog Index dan Cloze Test. Hasil penelitiannya menunjukkan bahwa wacana yang diteliti dalam buku teks tersebut memiliki tingkat keterbacaan instruksional atau sedang. Hal ini dapat ditunjukkan bahwa skor rata-rata yang diperoleh siswa yaitu $56,3 \%$.

Penelitian keterbacaan wacana buku teks pelajaran bahasa Indonesia juga pernah dilakukan oleh (Salihah, 2011) Universitas Negeri Makassar (UNM) meneliti tentang Keterbacaan Wacana Buku Teks Pelajaran Bahasa Indonesia Kelas X MAN 2 Watampone. Hasil penelitianya menunjukkan bahwa wacana yang diteliti dalam buku teks tersebut memiliki tingkat keterbacaan $44,8 \%$ yaitu berada pada tingkat instruksional/sedang.

\section{METODE PENELITIAN}

Variabel pada penelitian ini adalah Keterbacaan Buku Teks yaitu ukuran tingkat terbaca atau tidaknya wacana pada buku teks pelajaran bahasa Indonesia "Ekspresi Diri dan Akademik" cetakan kedua kelas X SMAN 1 Makassar dalam rangka dicerna, dipahami, dan dihayati oleh pembaca dalam hal ini siswa, yang diklasifikasikan menjadi tingkat baca independen, instruksional, dan frustasi. Keterbacaan terukur melalui metode Cloze Test.

Penelitian ini menggunakan metode survei kuantitatif yang mendeskripsikan keterbacaan buku teks bahasa Indonesia "Ekspresi Diri dan Akademik" cetakan kedua pada siswa kelas X SMAN 1 Makassar. Populasi pada penelitian ini adalah seluruh siswa kelas $X$ SMAN 1 Makassar, yang terbagi menjadi 11 kelas, yang terdiri dari delapan kelas untuk MIA (Matematika dan Ilmu Alam) dan tiga kelas untuk IIS (Ilmu-Ilmu Sosial) Siswa kelas X Tersebut menggunakan buku teks bahasa Indonesia "Ekspresi Diri dan Akademik" cetakan kedua sebagai salah satu sumber belajar pada mata pelajaran bahasa indonesia. Penarikan sampel dilakukan pada kelompok kelas MIA dan kelas IIS, dengan memilih secara acak masingmasing kelompok kelas tersebut. Setelah dilakukan penarikan sampel, kelompok kelas yang terpilih adalah kelompok kelas dari MIA 5 dan kelompok kelas dari IIS 3. Maka, sampel dari penelitian ini adalah 30 siswa dari kelompok kelas $\mathrm{X}$ MIA 5 dan $\mathrm{X}$ IIS 3 di SMAN 1 Makassar.

\section{HASIL PENELITIAN DAN PEMBAHASAAN}

Tingkat keterbacaan wacana dalam buku teks bahasa indonesia untuk kelas $\mathrm{X}$ sekolah menengah atas diukur dengan menggunakan test cloze. Data tentang tingkat keterbacaan wacana diperoleh berdasarkan hasil perolehan test cloze siswa kelas X SMAN 1 Makassar dari 8 wacana yang dipilih secara cluster random sampling.

\section{Hasil Penelitian \\ Skor Keterbacaan Wacana I}

Wacana I berjudul "Karbon" terdiri atas 4 paragraf dan 361 kata. Jenis wacana ini dianalisis untuk mengetahui tingkat keterbacaannya. Wacana tersebut memiliki skor teoretik $0-36$. Sebaran data skor empirik wacana I dengan responden 30 siswa adalah 20 35.

Responden yang mengisi semua isian yang benar memperoleh skor maximum 36. Dengan demikian, jumlah skor maksimal adalah $36 \times 30=1080$. Jumlah skor wacana yang diperoleh responden pada wacana I adalah 874 .

Tingkat keterbacaan $=\frac{874}{1080} \times 100=80,9$ Hasil yang diperoleh kemudian disesuaikan dengan tingkat keterbacaan $80,9 \%$ berada pada tingkat baca independen. Bacaan tersebut masih kurang layak dijadikan bahan ajar bagi siswa kelas X. Bahan bacaan yang terlalu mudah menjadikan siswa cepat merasa bosan terhadap bahan bacaan yang diajarkan sehingga menurunkan minat baca mereka.

\section{Skor Keterbacaan Wacana II}

Wacana II berjudul "Apa yang Harus Anda Lakukan Jika Ditilang" yang terdiri dari 306 kata dan 7 paragraf. Wacana tersebut memiliki skor teoretik $0-50$. Sebaran data skor empirik wacana II dengan responden 30 siswa adalah $10-44$. Responden yang mengisi semua isian yang benar memperoleh skor maximum 50. Dengan demikian, jumlah skor maksimal adalah $50 \times 30=1500$. Jumlah skor wacana 
yang diperoleh responden pada wacana II adalah 910 .

Tingkat keterbacaan $=\frac{910}{1500} \times 100=60,7$

Hasil yang diperoleh kemudian disesuaikan dengan tingkat keterbacaan $60,7 \%$ berada pada tingkat baca independen. Bacaan tersebut masih kurang layak dijadikan bahan ajar bagi siswa kelas $\mathrm{X}$.

\section{Skor Keterbacaan Wacana III}

Wacana III berjudul "Tata Cara Pemilihan Ketua RT dan Wakil Ketua RT" yang terdiri dari 343 kata dan 7 paragraf dengan skor teoretik $0-58$. Sebaran data skor empirik wacana III dengan responden 30 siswa adalah 653.

Responden yang mengisi semua isian yang benar memperoleh skor maximum 58. Dengan demikian, jumlah skor maksimal adalah $58 \times 30=1740$. Jumlah skor wacana yang diperoleh responden pada wacana III adalah 1072.

Tingkat keterbacaan $=\frac{1072}{1740} \times 100=61,6$
Hasil yang diperoleh $\quad$ kemudian disesuaikan dengan tingkat keterbacaan 61,6\% berada pada tingkat baca independen. Bacaan tersebut masih kurang layak dijadikan bahan ajar bagi siswa kelas $\mathrm{X}$.

\section{Skor Keterbacaan Wacana IV}

Wacana IV berjudul "Untung Rugi Perdagangan Bebas" yang terdiri dari 344 kata dan 7 paragraf dengan skor teoretik $0-54$. Sebaran data skor empirik wacana IV dengan responden 30 siswa adalah 18-54. Responden yang mengisi semua isian yang benar memperoleh skor maximum 36. Dengan demi-

kian, jumlah skor maksimal adalah $54 \times 30=$ 1620. Jumlah skor wacana yang diperoleh responden pada wacana IV adalah 1195.

Tingkat keterbacaan $=\frac{1195}{1620} \times 100=72,4$
Hasil yang diperoleh kemudian disesuaikan dengan tingkat keterbacaan 72,4\% berada pada tingkat baca independen. Bacaan tersebut masih kurang layak dijadikan bahan ajar bagi siswa kelas X.

\section{Skor Keterbacaan Wacana V}

Wacana V berjudul "Pemimpin Sosial dan Politik Tidak Harus Mempunyai Pendidikan Formal yang Tinggi" yang terdiri dari 271 kata dan 4 paragraf dengan skor teoretik $0-39$. Sebaran data skor empirik wacana V dengan responden 30 siswa adalah 21-39.

Responden yang mengisi semua isian yang benar memperoleh skor maximum 39. Dengan demikian, jumlah skor maksimal adalah $39 \times 30=1170$. Jumlah skor wacana yang diperoleh responden pada wacana $\mathrm{V}$ adalah 1048 .

Tingkat keterbacaan $=\frac{1048}{1170} \times 100=89,6$

Hasil yang diperoleh kemudian disesuaikan dengan tingkat keterbacaan $89,6 \%$ berada pada tingkat baca independen. Bacaan tersebut juga masih kurang layak dijadikan bahan ajar bagi siswa kelas $\mathrm{X}$.

\section{Skor Keterbacaan Wacana VI}

Wacana VI berjudul "Anekdot Hukum Peradilan" yang terdiri dari 672 kata dan 20 paragraf dengan skor teoretik $0-118$. Sebaran data skor empirik wacana VI dengan responden 30 siswa adalah 68-116.

Responden yang mengisi semua isian yang benar memperoleh skor maximum 36 . Dengan demikian, jumlah skor maksimal adalah $118 \times 30=3540$. Jumlah skor wacana yang diperoleh responden pada wacana I adalah 3132. Tingkat keterbacaan $=\frac{3132}{3540} \times 100=88,5$
Hasil yang diperoleh kemudian disesuaikan dengan tingkat keterbacaan $88,5 \%$ berada pada tingkat baca independen. Bacaan tersebut masih kurang layak dijadikan bahan ajar bagi siswa kelas $\mathrm{X}$.

\section{Skor Keterbacaan Wacana VII}

Wacana VII berjudul "Ekspor Kain Sarung ke Negeri Yaman" yang terdiri dari 489 kata dan 7 paragraf dengan skor teoretik $0-66$. Sebaran data skor empirik wacana VII dengan responden 30 siswa adalah 16-42.

Responden yang mengisi semua isian yang benar memperoleh skor maximum 66. Dengan 
demikian, jumlah skor maksimal adalah $66 \times 30=1980$. Jumlah skor wacana yang diperoleh responden pada wacana VII adalah 934.

Tingkat keterbacaan $=\frac{934}{1980} \times 100=47,2$

Hasil yang diperoleh kemudian disesuaikan dengan tingkat keterbacaan 47,2\% berada pada tingkat baca instruksional atau sedang. Bacaan tersebut layak dijadikan bahan ajar bagi siswa kelas $\mathrm{X}$.

\section{Skor Keterbacaan Wacana VIII}

Wacana VIII berjudul "Langkah Pelestarian Hewan Langka" yang terdiri dari 464 kata dan 8 paragraf dengan skor teoretik $0-61$.

Sebaran data skor empirik wacana VIII dengan responden 30 siswa adalah 12-40.

Responden yang mengisi semua isian yang benar memperoleh skor maximum 36. Dengan demikian, jumlah skor maksimal adalah $61 \times 30=1830$. Jumlah skor wacana yang diperoleh responden pada wacana VIII adalah 722.

Tingkat keterbacaan $=\frac{722}{1830} \times 100=39,5$

Berdasarkan gambaran persentase tingkat keterbacaan wacana VIII di atas, skor yang dicapai responden yaitu $39,5 \%$. Sesuai dengan kategori tingkat keterbacaan yang ditetapkan bahwa pembaca yang berada pada tingkat keterbacaan kisaran 41\% sampai dengan $60 \%$ berada pada tingkat baca frustasi/sulit. Jika pembaca berada pada tingkat baca frustasi/sulit berarti bahwa tingkat keterbacaan wacana tersebut tidak baik. Dengan demikian, wacana VIII kurang layak untuk dijadikan sebagai bahan ajar bagi siswa kelas X SMA. Bahan bacaan yang terlalu sulit dapat memperlambat siswa dalam belajar.

Rata-rata dari kedelapan wacana tersebut adalah sebanyak $68 \%$. Skor ini lebih besar dari $60 \%$ berarti keterbacaan wacana secara keseluruhan berada pada tingkat keterbacaan independen/mudah. Wacana-wacana tersebut kurang layak untuk dijadikan sebagai bahan ajar bagi siswa kelas X SMA. Dari delapan wacana terdapat enam wacana yang memiliki tingkat baca independen/mudah, kemudian hanya satu wacana yang memiliki tingkat baca instruksional/sedang dan satu wacana lagi yang memiliki tingkat baca frustasi/sulit. Ini berarti bahwa hanya satu wacana saja yang ada dalam buku teks tersebut yang layak dijadikan sebagai bahan ajar bagi siswa kelas X SMA sedangkan wacana yang lain itu masih kurang layak untuk dijadikan sebagai bahan ajar.

\section{PEMBAHASAN}

Keterbacaan wacana merupakan pengukuran tingkat kesulitan wacana dalam sebuah buku teks. Dari analisis keterbacaan dapat diketahui mudah atau tidaknya suatu wacana dalam rangka dicerna, dipahami, atau dihayati. Hasil tes keterbacaan didapatkan dengan menggunakan siswa sebagai responden. Skor siswa dihitung dari jumlah kata yang dijawab dengan benar. Siswa yang menjawab benar diberi skor 1 sedangkan siswa yang menjawab salah diberikan skor 0. Semakin banyak jumlah kata yang dapat dijawab dengan benar maka semakin tinggi tingkat keterbacaan sebuah wacana.

Delapan buah wacana yang telah diujikan kepada siswa kelas X SMA 1 Makassar dalam bentuk cloze test memperoleh hasil yang menunjukkan bahwa sebanyak enam wacana yang berada pada kategori tingkat keterbacaan independen/mudah, yaitu wacana I yang berjudul "Karbon" memiliki persentase 80,9\%, wacana II berjudul "Apa yang Harus Anda Lakukan Jika Ditilang" memiliki persentase $60,7 \%$, wacana III yang berjudul "Tata Cara Pemilihan Ketua RT dan Wakil Ketua RT" memiliki persentase $61,6 \%$, wacana IV yang berjudul "Untung Rugi Perdagangan Bebas" memiliki persentase $72,4 \%$, wacana $V$ yang berjudul "Pemimpin Sosial dan Politik Tidak Harus Mempunyai Pendidikan Formal yang Tinggi" memilik persentase $89,6 \%$, wacana VI yang berjudul "Anekdot Hukum Peradilan" memiliki persentase $88,5 \%$, wacana VII yang berjudul "Ekspor Kain Sarung ke Negeri Yaman" memiliki persentase $47,2 \%$ dan wacana VIII yang berjudul "Langkah Pelestarian Hewan" memiliki persentase 39,5.

Bahan bacaan yang baik adalah bahan bacaan terlalu sulit dan juga tidak terlalu mudah. Hal ini sejalan dengan apa yang diungkapkan (Suladi dkk. 2000; 4) bahwa jika suatu wacana itu terlalu sulit, pembaca akan membaca dengan agak sedikit lambat bahkan kadang-kadang berulang-ulang agar dapat memahami isinya. 
Hal itu kemungkinan dapat menyebabkan seorang pembaca menjadi frustasi karena apa yang diharapkan mungkin tidak akan tercapai. Namun, jika suatu wacana itu terlalu mudah, seorang pembaca akan cepat merasa bosan. Untuk itu, diperlukan wacana yang dianggap sesuai untuk kelompoknya.

Berdasarkan persentase tingkat keterbacaan kedelapan wacana di atas, rangkuman persentase tingkat keterbacaan adalah 68\% yaitu berada pada tingkat keterbacaan independen/mudah. Dengan demikian, buku teks yang dipergunakan pada siswa kelas X SMAN 1 Makassar tergolong wacana yang kurang baik dalam artian bahwa wacana tersebut terlalu mudah. Hal tersebut dapat mengakibatkan siswa akan cepat merasa bosan untuk membaca dan mengakibatkan minat baca siswa akan berkurang sehingga kurang baik untuk dijadikan sebagai bahan ajar bagi siswa kelas X SMA.

Keterbacaan suatu materi pelajaran harus menjadi perhatian utama para guru agar siswa dapat memeroleh proses dan hasil belajar yang maksimal. Temuan peneliti tentang faktorfaktor yang memengaruhi keterbacaan, antara lain; panjang kalimat dan tingkat kesulitan kata. Hal tersebut sejalan dengan yang dikemukakan oleh (Harjasujana dan Mulyati dalam Shaliha, 2011;61) bahwa ada dua faktor yang berpengaruh terhadap keterbacaan suatu wacana, yaitu (1) panjang pendeknya kalimat, dan (2) tingkat kesulitan kata. Pada umumnya, semakin panjang kalimat dan semakin panjang katakatanya, bacaannya semakin sukar, sebaliknya, jika kalimat dan dan kata-katanya pendekpendek, maka wacana itu tergolong wacana sedang atau baik. Hal ini terjadi pada wacan VII yang berjudul "Ekspor Kain Sarung ke Negeri Yaman" memiliki kalimat yang panjang. Kalimat yang panjang akan menyulitkan siswa dalam memahaminya. Seperti pada paragraf pertama " kain sarung ternyata tidak hanya digemari oleh masyarakat Indonesia, tetapi juga oleh masyarakat di negara-negara lain, seperti Malaysia, Brunei Darussalam, Filipina, hingga ke negeri Asia Tengah, seperti India, Pakistan, dan Bangladesh".

Kalimat yang panjang tidak hanya terdapat dalam wacana VII tetapi juga terdapat pada wacana VIII pada paragraf ke delapan dalam kalimat pertama terdiri atas 49 kata.
Hal tersebut tidak sesuai dengan apa yang dikemukakan oleh (Nurhadi dalam Shaliha, 2011; 62) bahwa kalimat yang mudah dipahami adalah kalimat yang terdiri dari 8-12 kata dalam satu kalimat agar pembaca memahami kalimat itu secara utuh dan tidak terputus karena katakata dalam kalimat tersebut tidak terlalu banyak. Kalimat yang panjang dalam wacana VIII menjadi salah satu penyebab rendahnya tingkat keterbacaan wacana tersebut.

(Suladi dkk. dalam Shaliha, 2011; 63) memberi batasan kata yang sulit itu berupa kata yang terdiri atas lebih dari tiga suku kata, kata yang bukan kata pertama dalam kalimat yang diawali dengan huruf kapital dikategorikan juga sebagai kata yang sulit.

Beberapa kata-kata yang dijadikan sampel dalam penelitian mempunyai tingkat kesulitan kata yang bervariasi. Pemakaian kata yang menimbulkan ambiguitas merupakan salah satu penyebab wacana memiliki tingkat keterbacaan yang rendah ini terlihat pada wacana II, seperti kata pembimbing, alternatif, seragamnya.

Keterbacaan tidak hanya ditentukan oleh panjang kalimat, susunan kata, dan kesulitan kata, tetapi juga ditentukan oleh pembendaharaan kata yang dimiliki oleh siswa yang menjadikan respon yang kurang. Kekurangan perbendaharaan kata yang kurang menjadikan siswa sulit untuk mengisi kata yang dikosongkan. Isi wacana yang tidak dikenal siswa juga memengaruhi tingkat keterbacaan. Hal ini dapat dilihat dari hasil tingkat keterbacaan wacana VII dan VIII, masingmasing berada pada tingkat baca instruksional/sedang dan tingkat baca frustasi/sulit. Pada kedua wacana tersebut terdapat beberapa kata yang belum dikenal siswa seperti kata "idealismenya" pada wacana VII paragraf keenam dan kata "terintegrasi" pada wacana VIII paragraf kedua. Hal ini dibuktikan bahwa sejumlah besar siswa responden menjawab salah pada kedua kata-kata tersebut. Adanya pemilihan kata yang kurang tepat, perbedaan pendidikan antara penulis dengan siswa, bahasa yang digunakan dan sebagainya yang menjadikan wacana tersebut tergolong sulit sehingga siswa tidak dapat menerima atau kurang menangkap maksud yang disampaikan oleh penulis. 


\section{KESIMPULAN}

Berdasarkan analisis dan pembahasan hasil penelitian, penulis dapat menarik kesimpulan sebagai berikut:

Dari delapan wacana yang diujikan kepada siswa ada enam wacana yang berada pada tingkat baca independen/mudah, yaitu wacana wacana I yang berjudul "Karbon" memiliki persentase $80,9 \%$, wacana II berjudul "Apa yang Harus Anda Lakukan Jika Ditilang" memiliki persentase $60,7 \%$, wacana III yang berjudul "Tata Cara Pemilihan Ketua RT dan Wakil Ketua RT" memiliki persentase 61,6\%, wacana IV yang berjudul "Untung Rugi Perdagangan Bebas" memiliki persentase $72,4 \%$, wacana V yang berjudul "Pemimpin Sosial dan Politik Tidak Harus Mempunyai Pendidikan Formal yang Tinggi" memilik persentase $89,6 \%$, wacana VI yang berjudul "Anekdot Hukum Peradilan" memiliki persentase $88,5 \%$.

\section{DAFTAR PUSTAKA}

Djajasudarma, T. Fatimah. 2006. Wacana. Bandung: Penerbit Refika Utama.

Harjasujana, Akhmad Slamet dan Yeti Mulyati. 1996. Membaca 2. Jakarta: Departemen Pendidikan dan Kebudayaan.

Pusat Bahasa Departemen Pendidikan Nasional. 2008. Kamus Besar Bahasa Indonesia (Edisi Keempat). Jakarta: Balai Pustaka.

Kridalaksana, Harimurti. 2008. Kamus Linguistik. Jakarta: Penerbit PT. Gramedia Pustaka.

Magdalena, Ina. 2013.Keterbacaan Buku teks "Bina Bahasa Indonesia" Untuk Siswa Kelas V Terbitan E di SDN Pademangan Timur 04 Petang Jakarta Utara Melalui Metode Fog Indeks dan Cloze Test.(Tesis).UNJ: Program Pascasarjana.

M.S Mahsun. 2014. Metode Penelitian Bahasa. Jakarta: PT RajaGrafindo Persada.

Ormrod, Jeanne Ellis. 2008. Psikologi Pendidikan. Jakarta: Penerbit Erlangga.

Patombongi, A. Wardihan dkk. 2008. Telaah Kurikulum Bahasa Indonesia. Makassar: Badan Penerbit UNM.
Terdapat satu wacana yang tergolong kategori tingkat baca instruksional/sedang yaitu wacana VII yang berjudul "Ekspor Kain Sarung ke Negeri Yaman" memiliki persentase 47,2\% dan satu wacana yang tergolong kategori tingkat baca frustasi/sulit yaitu wacana VIII yang berjudul "Langkah Pelestarian Hewan" memiliki persentase 39,5.

Rata-rata tingkat baca keseluruhan wacana adalah $68 \%$ berada pada kategori tingkat baca independen/mudah yang menandakan bahwa tingkat keterbacaan wacana sangat tinggi. Hasil seperti itu menjadikan wacana yang ada dalam Buku Teks Pelajaran Bahasa Indonesia "Ekspresi Diri dan Akademik" Cetakan Kedua pada Siswa Kelas X yang ditulis oleh Kementerian Pendidikan dan Kebudayaan masih kurang baik untuk dijadikan sebagai bahan ajar.

Rahim, Abd. Rahman. dkk. 2007. Budi Bahasa "Keterampilan Membaca Mahasiswa Perguruan Tinggi Swasta di Sulawesi Selatan". Makassar: Badan Penerbit UNM.

Sitepu, B.P. Keterbacaan. 2010. (Online) https://binta ngsitepu.wordpress.com/2010/09/11/keterbaca an/.

Suladi, dkk. 2000. Keterbacaan Kalimat Bahasa Indonesia dalam Buku Pelajaran SLTP. Jakarta: Depdiknas.

Santrock, John W. 2007. Remaja. Jakarta: Penerbit Erlangga.

Shaliha, Sitti. 2011.Keterbacaan Wacana Buku Teks Pelajaran Bahasa Indonesia Kelas X MAN 2 Watampone.(Tesis) Makassar: Penerbit PPs UNM.

Syamsuddin dkk. 1997. Studi Wacana Bahasa Indonesia. Jakarta: Departemen Pendidikan dan Kebudayaan.

Tarigan, Henry Guntur. dkk. 1999. Telaah Buku Teks Bahasa Indonesia. Bandung: Penerbit Angkasa Bandung. 